\title{
Heavy Metal Accumulation in Cockscomb (Celosia Argentea Linn) Grown in Soil Amended With Chicken Manure
}

Oladele Abdulahi Oguntade ( $\nabla$ deletade@yahoo.com )

Olabisi Onabanjo University College of Agricultural Sciences https://orcid.org/0000-0002-0825-5089

Nosiru Monday Yisa

Olabisi Onabanjo University College of Agricultural Sciences

Solomon Oladimeji Olagunju

Olabisi Onabanjo University College of Agricultural Sciences

Olufemi Sunday Sosanya

Olabisi Onabanjo University College of Agricultural Sciences

Abiodun Oladipupo Joda

Olabisi Onabanjo University College of Agricultural Sciences

Kayode Matthew Adewusi

Olabisi Onabanjo University College of Agricultural Sciences

Richard Oluseyi Olayiwola

Olabisi Onabanjo University College of Agricultural Sciences

\section{Research Article}

Keywords: Bioaccumulation, Celosia, Chicken manure, Edible tissues, Heavy metals, Pollution indices, Soil

Posted Date: November 23rd, 2021

DOI: https://doi.org/10.21203/rs.3.rs-1011518/v1

License: (9) This work is licensed under a Creative Commons Attribution 4.0 International License.

Read Full License 


\section{Heavy metal accumulation in Cockscomb (Celosia argentea Linn) grown in soil amended with \\ 2 chicken manure}

3

4

Oladele Abdulahi Oguntade*, Nosiru Monday Yisa, Solomon Oladimeji Olagunju, Olufemi Sunday Sosanya, Abiodun Oladipupo Joda, Kayode Matthew Adewusi and Richard Oluseyi Olayiwola

Department of Crop Production, College of Agricultural Sciences, Olabisi Onabanjo University, P.M.B. 0012, Ayetoro Campus, Ayetoro, Ogun State, Nigeria.

"Corresponding author: deletade@yahoo.com; dele.oguntade@oouagoiwoye.edu.ng

Telephone: +234 8035232706; ORCID Number: 0000-0002-0825-5089

ORCID Number: 0000-0001-7429-5030 (S.O. Olagunju)

ORCID Number: 0000-0002-1711-4843 (O.S. Sosanya)

ORCID Number: 0000-0001-9208-1589 (A.O. Joda)

ORCID Number: 0000-0001-5021-059x (K.M. Adewusi)

ORCID Number: 0000-0003-3969-8445 (R.O. Olayiwola)

\section{Abstract}

Heavy metals such as Cadmium $(\mathrm{Cd})$, Copper $(\mathrm{Cu})$ and Manganese $(\mathrm{Mn})$ in chicken manure can contaminate soil and bioaccumulate in edible tissues of plant to cause food chain contamination. This study investigated the influence of chicken manure on heavy metal load of soil and accumulation in tissues of Celosia argentea. Air-dried chicken manure from battery cages (conventional chicken manureCCM) and free range birds (local chicken manure-LCM) were used for the pot culture. Chicken manure was applied as amendment at the rate of $0,4,6,8$ and $10 \mathrm{t} \mathrm{ha}^{-1}$ in $5 \mathrm{~kg}$ soil. Treatments were replicated trice in a Completely Randomized Design. Results showed that soil metal pollution increased with rates of amendment. Metal pollution indices; contamination factor, degree of contamination, elemental pollution index, pollution load index and total contamination factor were significantly $(p \leq 0.001)$ higher in soil amended with CCM than LCM. Bioaccumulation coefficients (BAC), bioaccumulation factor 
27 (BAF) and transfer factor (TF) of metals were higher in tissues of celosia grown with CCM than LCM.

28 Furthermore, above $4 \mathrm{t} \mathrm{ha}^{-1}$, growth and yield were not significantly influenced by amendment rates.

29 Mobility of metals from soil to tissues of celosia increased in the order $\mathrm{Cu}>\mathrm{Mn}>\mathrm{Cd}$. Chicken manure 30 above $4 \mathrm{tha}^{-1}$ potent health risks of $\mathrm{Cu}$ exposure to consumers of celosia.

31 Keywords: Bioaccumulation. Celosia. Chicken manure. Edible tissues. Heavy metals. Pollution indices. 32 Soil.

\section{Introduction}

35 Meeting the demand for healthy and safe food has led to intensive organic farming where soil amendment with animal manure has become the global practice among farmers. Animal manure especially from

37 poultry birds is a rich and good source of plant nutrients that are eco-friendly unlike inorganic fertilizers (Mortola et al. 2019; Oguntade et al. 2019). The consequence of over utilization of animal manure on heavy metal pollution of soil is of environmental concern. This is because of its associated threat to ecosystem and possible food chain contamination (Eugenio et al. 2020; Oguntade et al. 2020). Although, the geochemical characteristics of soils generally possess some background levels of nutrient elements

42 including metals which are inherent in them but often does not cause pollution. Application of chicken 43 manure amendment to soils for organic farming is on the trend that requires attention to reduce soil 44 pollution and minimize contamination of food crops. This is because livestock manure including poultry 45 waste has been recognized as a source of heavy metal contaminant to agricultural soils while improving 46 soil fertility (Hanč et al. 2008; Luo et al. 2009; Oguntade et al. 2018). Hence, unconscious deposition of 47 metal contaminants in soils through over fertilization with manure can increase heavy metal load of soil, contaminate food crops and endanger soil health and food chain (Khan et al. 2017; Kobierski et al. 2017).

Plant nutrients and toxic metals found in chicken manure are primarily from the concentrate 50 feeds, supplements and veterinary drugs given to the birds (Nicholson et al. 1999; Adeli et al. 2007; 51 Chastain et al. 2010; Oguntade et al. 2019). More often residues of metals in amended soils is dependent 
52 on the quality and quantity of manure applied (Nicholson et al. 1999; He et al. 2009). Studies have shown

53 high levels of toxic metals including arsenic, iron, zinc, copper, cadmium, chromium, manganese and lead

54 in soils amended with chicken manure sourced from conventional battery cages (Zhang et al. 2012;

55 Oguntade, et al. 2017). The manure is enriched with toxic metals because some of the trace metals

56 consumed by the chicken are not absorbed through the digestive system (Adeli et al. 2007). However,

57 little is documented on the environmental impact of metallic elements in manure of local chicken raised

58 on free range system. Free range locally raised chicken depend on foods like insects, worms/larva and

59 grasses from the natural or wild environment. The source of feed for local chicken perhaps is an

60 indication of low levels of toxic metals in its manure and applying such could reduce metal loads in soils.

Copper $(\mathrm{Cu})$, cadmium $(\mathrm{Cd})$ and manganese $(\mathrm{Mn})$ are among the trace metals found in the feed

62 additives and supplements given to chicken kept in battery cages for optimal production (Oguntade et al.

63 2018). These metals have densities greater than $5 \mathrm{~g} \mathrm{~cm}^{-3}$, long biological half-life and their presence in

64 chicken manure at elevated concentration may cause pollution of amended soil. Soil amendment with

65 livestock manure can enhance accumulation of trace metals in soils and become available for crop uptake

66 (Antonious et al. 2012; Wajid et al. 2020; Ugulu et al. 2021). Since soil-plant movement of trace elements

67 is part of the natural means of nutrient cycling. However, consumption of crops that bio-accumulate trace

68 metals in its edible part is one of the means of human exposure to toxic metals and could be life

69 threatening. This is because of the damaging effects toxic metals could have on body organs such as the

70 brain, lungs, liver and kidney (Salem et al. 2000; Bandow and Simon 2016; Shakoor et al. 2016).

Pollution load index is one of the means for assessing intensity of heavy metal pollution of soils

72 (Jorfi et al. 2017). Pollution indices can give quantitative assessment of soil pollution levels from build-up

73 of toxic metals through agricultural activities (Shomar and Kalavrouziotis 2013). Furthermore, it is a

74 useful tool for monitoring and evaluating the degree of soil contamination for predicting sustainability in

75 agro-ecosystems (Kowalska et al. 2018). Several authors including (Cabrera et al. 1999; Hough et al.

76 2003; Kalavrouziotis and Koukoulakis 2012) have developed various pollution indices for monitoring 
77

and assessing heavy metal risks in soil-plant system. Among these indices are; contamination factor (CF), degree of contamination (DC), elemental pollution index (EPI) and pollution load index (PLI). However, it may not be enough to assess pollution potential of soil amended with chicken manure without evaluating extraction and bioaccumulation potentials of celosia grown on such soil. This is germane when monitoring metal transfer through soil-plants-human system. Studies have shown that crops growing on metal contaminated soils and environment cannot prevent metal uptake but can only restrict accumulation concentration in the plant tissues depending on the metal (Baker 1981; Jamali et al. 2009; Oguntade et al. 2020). Properties such as Bioconcentration factor (BCF), Bioaccumulation coefficient (BAC) and Translocation factor (TF) are often used in evaluating toxic metals accumulation potentials of plants (Yoon et al. 2006; Amin et al. 2018; Simanek and Holden 2020). These properties can give insights on the ability of celosia in translocating metals taken up from manure amended soil into its edible shoot. Knowledge provided thereof is expedient for valuable information on better management of chicken manure in promoting organic farming for healthy soil, improved yield and better quality of crops.

Cockscomb (Celosia argentea Linn) is a leafy vegetable that is rich in nutrients and other essential minerals required for balanced diet. Besides, it is a popular vegetable among farmers in western Nigeria because of its fast growth rate and yield in addition to possibility of several harvests from a single plant (Oguntade et al. 2017; Oguntade et al. 2020). Celosia is one of the vegetable that has the potentials of accumulating heavy metals in its edible and non-edible parts beyond allowable limits when grown on contaminated soils and environment (Alam et al. 2003; Yoon et al. 2006; Oguntade et al. 2020). Dietary consequence of consuming such vegetable can constitute health related problems. This study therefore aimed to investigate; (i) accumulation of heavy metals in soil amended with chicken manure from different sources, (ii) determine pollution index of the soil and (iii) bioaccumulation in celosia tissues through metal transfer to edible and non-edible parts.

\section{Materials and methods}

\section{Study area}


The study was carried out at the Department of Crop Production, College of Agricultural Sciences, Ayetoro campus of Olabisi Onabanjo University, Nigeria. Soil used for the study was collected from the field lying on latitude $7.2339^{\circ} \mathrm{N}$, longitude $3.0595^{\circ} \mathrm{E}$ and $109.75 \mathrm{~m}$ above sea level at Teaching and Research Farm of the College.

\section{Soil and chicken manure collection and preparation}

107 The soil was collected from 0-15 cm depth at the farm and air-dried for 7 days. Following drying, soil for 108 the pot experiment was sieved with $7 \mathrm{~mm}$ mesh to remove stone and plant debris. Sub-sample for physicochemical analysis was however sieved with $2 \mathrm{~mm}$ mesh. Fresh droppings from layers bird in battery cages used as conventional chicken manure (CCM) was collected from the College's poultry farm.

111 The layer birds were on concentrate feed compounded from maize and groundnut cake (Oguntade et al.

112 2019). Local chicken droppings from free range system (LCM) were also collected within Ayetoro town 113 from their coop/chicken pens. Collected droppings were air-dried for 4 weeks, crushed and sieved with 7 $114 \mathrm{~mm}$ mesh. Sub-samples each of the soil and manure were subsequently taken for laboratory analysis.

\section{Experimental setup}

Buckets of 7 litre capacity each was filled with $5 \mathrm{~kg}$ soil homogenized with each type of amended chicken

117 manure at the rate of 0 (control), 4, 6, 8 and $10 \mathrm{tha}^{-1}$ on dry weight $(d / w)$ basis. The study was a factorial 118 experiment fitted into a completely randomized design (CRD) and replicated three times. The amended 119 potted soils were left for two weeks prior to sowing of cockscomb (Celosia argentea) seeds. Seedlings of 120 the leafy vegetable were thinned to one stand per pot 2 weeks after sowing (WAS). Each pot was watered with $250 \mathrm{mls}$ of fresh water every other day for the first 3 weeks and thereafter every day until 6 WAS

122 when plants were harvested. Weeds from each pot were removed manually and returned in-situ per pot. 123 At harvesting, plant height, numbers of leave and primary branches were recorded. Plants samples were thereafter separated into its edible (shoot) and non-edible (root) parts. Each plant part was separately 
and fresh weights determined. Plant samples were later oven-dried at $65{ }^{\circ} \mathrm{C}$ to constant weight for determination of dry weight and then ground for chemical analysis. Sub-sample of soils from each pot was also taken for laboratory analysis.

\section{Chicken manure analysis}

The $\mathrm{pH}$ of the chicken manure was determined with glass electrode $\mathrm{pH}$ meter. Concentrations of calcium, $(\mathrm{Ca})$, magnesium $(\mathrm{Mg})$, potassium $(\mathrm{K})$, sodium $(\mathrm{Na})$ as well as copper $(\mathrm{Cu})$, iron $(\mathrm{Fe})$, manganese $(\mathrm{Mn})$ Zinc $(\mathrm{Zn})$ cobalt $(\mathrm{Co})$, nickel $(\mathrm{Ni})$, chromium $(\mathrm{Cr})$, cadmium $(\mathrm{Cd})$ and lead $(\mathrm{Pb})$ were also determined. The analyses were carried out with the use of atomic absorption spectrophotometer, AAS (Buck Scientific 210VGP Model, Inc., East Norwalk, CT, USA) according to Udo et al. (2009). Total Organic carbon (OC) was determined by wet oxidation method (Nelson and Sommer 1996) and nitrogen (N) by Kjeldahl method (Bremner and Mulvaney 1982). Phosphorus (P) content was determined by colourimetric method (Nelson and Sommers 1996).

\section{Soil analysis}

The soil's $\mathrm{pH}$ was determined with glass electrode $\mathrm{pH}$ meter in 1:2 soil/water suspension (McLean et al., 1982). Exchangeable bases $\left(\mathrm{Ca}^{2+}, \mathrm{Mg}^{2+}, \mathrm{K}^{+}\right.$and $\left.\mathrm{Na}^{+}\right)$in the soil were extracted with $1 \mathrm{~N}$ ammonium acetate solution. Calcium and $\mathrm{Mg}^{2+}$ were determined with AAS while $\mathrm{K}^{+}$and $\mathrm{Na}^{+}$were read on flame photometer. The soil exchangeable acidity $\left(\mathrm{Al}^{3+}+\mathrm{H}^{+}\right)$was extracted with $1 \mathrm{~N} \mathrm{KCl}$ solution and determined by titration method (Anderson and Ingram 1993). Effective cation exchange capacity (ECEC) was estimated as addition of exchangeable bases and acidity. Base saturation (BS) was calculated in percentage as the ratio of exchangeable bases to ECEC according to Udo et al. (2009). Total Organic carbon was determined by oxidation method (Walkley and Black 1934), while total $\mathrm{N}$ was determined by macro-Kjeldahl method (Bremner and Mulvaney 1982). Extractable P was determined by Bray-1 method (Nelson and Sommers 1996). Particle size analysis of the soil was determined by the hydrometer method (Bouyoucos 1962). Heavy metals (Cu, Fe, Mn, Zn, Co, Ni, Cr, Cd and Pb) in the soil were determined on 
atomic absorption spectrophotometer-AAS (Udo et al. 2009).

\section{Plant analysis}

152 Plant samples $(0.5 \mathrm{~g})$ were digested with $10 \mathrm{ml}$ concentrated nitric $\left(\mathrm{HNO}_{3}\right)$ and perchloric $\left(\mathrm{HClO}_{4}\right)$ acids

$153(2: 1 \mathrm{v} / \mathrm{v})$ for the first 90 minutes at $150{ }^{\circ} \mathrm{C}$. Thereafter, $2 \mathrm{ml}$ concentrated $\mathrm{HCl}$ was added to the digests

154 and the temperature was raised to $230{ }^{\circ} \mathrm{C}$ for the next 30 minutes. Digested samples were cooled down at 155 room temperature, digests transferred to $50 \mathrm{ml}$ volumetric flask and diluted to volume with deionized 156 water. The total contents of $\mathrm{Cu}, \mathrm{Cd}$ and $\mathrm{Mn}$ in the digests were then determined by AAS (Buck Scientific 157210 VGP model, Inc., East Norwalk, CT, USA) according to Udo et al. (2009).

\section{Soil contamination measurement}

\section{Contamination factor $(\mathbf{C F})$}

160 The soil contamination or pollution factor was determined according to the equation (Håkanson 1980);

$161 \mathrm{CF}=\frac{\mathrm{C} \text { metal }}{\mathrm{C} \text { bkg }}$

Equation

162 where $\mathrm{C}$ metal is the concentration $\left(\mathrm{mg} \mathrm{kg}^{-1}\right)$ of a given heavy metal in soil and $\mathrm{C}$ bkg is the background 163 or preindustrial concentrations $\left(\mathrm{mg} \mathrm{kg}^{-1}\right)$. For the pre industrial concentration of metals, we adopted 164 values reported by Turekian and Wedepohl (1961) for carbonate soils with similar sedimentary origin. 165 The geochemical background concentration values of $\mathrm{Cd}, \mathrm{Cu}$ and $\mathrm{Mn}$ were; $0.035,4.0$ and $1100.0 \mathrm{mg} \mathrm{kg}^{-}$

$166{ }^{1}$, respectively. The selected metals were among trace elements found in drugs and supplements given to 167 the conventionally raised chicken (Oguntade et al. 2019), residues of which might be in the amended soil. Degree of contamination (DC)

169 Degree of contamination of the soil by the selected metals was calculated as the sum of the CFs, 170 according to Fiori et al. (2013) as follows:

$171 \quad \mathrm{DC}=\sum \mathrm{CF}$ Equation 
172 The degree of soil contamination has been categorized into four as follows depending on intensity. Low

$173 \mathrm{CF}<1$; moderate $1<\mathrm{CF}<3$; considerable $3<\mathrm{CF}<6$; high $\mathrm{CF}>6$ (Gong et al. 2008; Islam et al. 2015).

\section{Total contamination factor (TCF)}

175 The $\mathrm{TCF}=(M 1+M 2+M 3+\cdots M n) /(M 1 r+M 2 r+M 3 r+\cdots M n r) \quad$ Equation $\quad \ldots \ldots$

176 where; $M 1, M 2, M 3+\ldots . M n$ represents the selected heavy metals, $(M 1 r+M 2 r+M 3 r+\ldots . M n r)$ are the

177 corresponding reference values of the metals with $n$ as the number of analyzed heavy metals $\left(\mathrm{mg} \mathrm{kg}^{-1}\right)$

178 (Shomar and Kalavrouziotis 2013).

179

Elemental pollution index (EPI)

180

The EPI was calculated as follows; EPI $=n \sqrt{M 1 \times M 2 \times M 3 \ldots \ldots M n}$

Equation

181 where; $M 1, M 2, M 3, \ldots M n$, represents the selected heavy metals (Shomar and Kalavrouziotis 2013)

\section{Pollution load index (PLI)}

183 The PLI was calculated according to (Tomlinson et al. 1980) as;

selected metals. According to Tomlinson et al. (1980), pollution levels are categorized as follows; no contamination (PLI < 1); moderate contamination (1 2); severe contamination (2 5); extreme contamination (PLI $\geq 5)$.

\section{Phytoextraction efficiency}

In order to determine heavy metal phytoextraction potential of Celosia argentea grown on soil amended with chicken manure, the plant Bioconcentration factor (BCF), Bioaccumulation coefficient (BAC) and 
194 Bioconcentration factor was calculated as; $\mathrm{BCF}=\frac{\mathrm{C} \text { root }}{\mathrm{C} \text { soil }}$
Bioaccumulation coefficient was calculated as; $\mathrm{BAC}=\frac{\mathrm{C} \text { shoot }}{\mathrm{C} \text { soil }}$

Translocation factor was calculated as; $\mathrm{TF}=\frac{\mathrm{C} \text { shoot }}{\mathrm{C} \text { root }}$ respectively.

\section{Statistical analysis} pollution and accumulation in plant tissues.

\section{Results and discussion}

Equation

Equation

Equation where; $\mathrm{C}_{\text {root }}, \mathrm{C}_{\text {shoot }}$ and $\mathrm{C}_{\text {soil }}$ are concentrations $\left(\mathrm{mg} \mathrm{kg}^{-1}\right)$ of heavy metals in root, shoot and soil,

All data generated were subjected to analysis of variance (ANOVA). Significant treatment means were separated by Fisher's protected Least Significant Difference (LSD) at 5\% level of probability. Pearson's moment correlation analysis (r) and Principal Component Analysis (PCA) were also carried out to determine the association between the manure types and rates on soil chemical properties, soil metal

Physicochemical characteristics of soil and chicken manure used for this study are shown in Table 1 . The $\mathrm{pH}$ of the soil was moderately acidic. The soil was high in exchangeable bases ( $\mathrm{Ca}, \mathrm{Mg}, \mathrm{K}$ and $\mathrm{Na})$ with low level of exchangeable acidity. Effective CEC of the soil was above the critical level of $6.0 \mathrm{cmol} \mathrm{kg}^{-1}$ reported by Esu (1991). The base saturation was high, indicating dominance of basic cations at the soils exchange complex. Organic carbon was moderate (FAO 1976; Udo et al. 2009) while total N of $1.73 \mathrm{~g}$ $\mathrm{kg}^{-1}$ in the soil falls within the critical level of 1.5-2.0 $\mathrm{g} \mathrm{kg}^{-1}$ (Sobulo and Osiname 1981). The extractable $\mathrm{P}$ was lower than critical range of 10-16 $\mathrm{mg} \mathrm{kg}^{-1}$ (Adeoye and Agboola 1985). Hence, for optimal growth and yield of celosia in this type of soil, addition of organic amendment such as chicken manure may be 
Table 1 Physicochemical properties of the experimental soil and chicken manure amendments

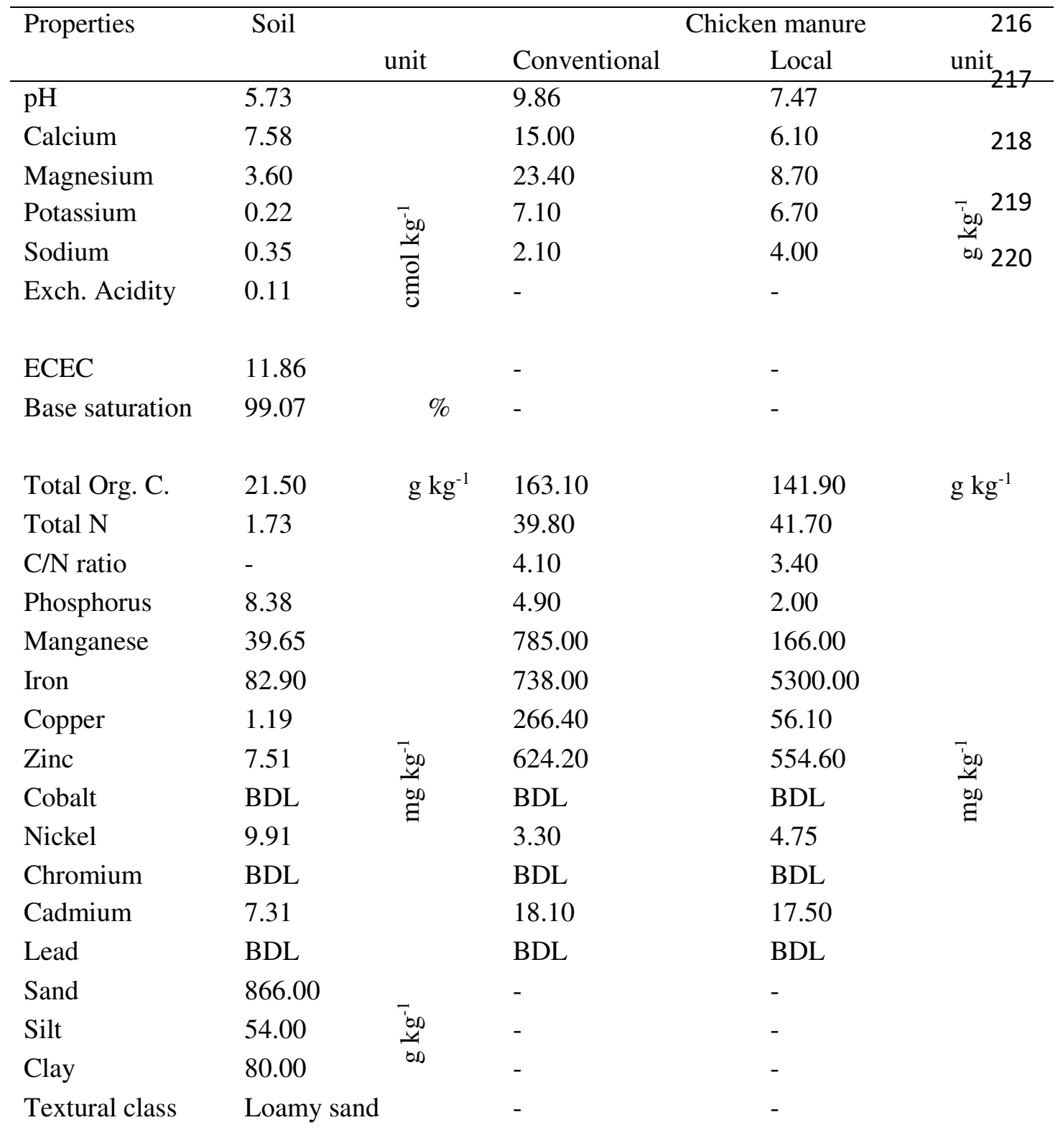

$\mathrm{BDL}=$ below detection limits of $0.05,0.003$ and $0.04 \mathrm{mg} \mathrm{kg}^{-1}$ for $\mathrm{Co}, \mathrm{Cr}$ and $\mathrm{Pb}$, respectively. 
necessary. Manganese and $\mathrm{Fe}$ in the soil were high, while $\mathrm{Cu}$ level was within the critical limit of 0.21 $2.0 \mathrm{mg} \mathrm{kg}^{-1}$ reported by Esu (1991). Extractable Zn was also higher than critical soil range of 0.8-2.0 mg $\mathrm{kg}^{-1}$ (Esu 1991). Cobalt, $\mathrm{Cr}$ and $\mathrm{Pb}$ were below soil detection limits while $\mathrm{Ni}$ and $\mathrm{Cd}$ were 9.91 and 7.31 $227 \mathrm{mg} \mathrm{kg}^{-1}$, respectively. The soil was inherently high in extractable Cd since it has value higher than $3 \mathrm{mg}$ $228 \mathrm{~kg}^{-1}$ limit recommended by FAO/WHO (2001) and European Commission (2006). while that of LCM was very slightly alkaline (Table 1). Calcium and Mg were more than two folds higher in conventional than local manure. This could be attributed to the composition of diet given to egg laying birds in the battery cages. Potassium content in the CCM was also higher than that in the LCM but Na content of LCM was almost double the amount in CCM. Total organic carbon in CCM was higher than in LCM but the trend was reversed for total $\mathrm{N}$. The lower N content in CCM than LCM could be due to mobility of $\mathrm{N}$ from volatilization in $\mathrm{CCM}$ during air-drying. The $\mathrm{C} / \mathrm{N}$ ratio of the $\mathrm{CCM}$ was higher than that of the LCM and was a reflection of the carbon content of the manure. Phosphorus concentration in 237 CCM was more than double that of LCM. Manganese was more than four folds higher in conventional 238 than local manure. Meanwhile, Iron was seven folds higher in local than conventional manure. 239 Concentration of $\mathrm{Cu}$ was more than four times higher in CCM than LCM. Zinc was also higher in conventional than local manure. Nickel followed the pattern of Fe with higher content in local than conventional manure. Cadmium was also higher in conventional than local manure. The higher contents of Fe and Ni in LCM than CCM could be traced to what the birds fed on including small stones and pebbles form the surrounding soil. Conversely, high concentrations of $\mathrm{Mn}, \mathrm{Cu}, \mathrm{Zn}$ and $\mathrm{Cd}$ in $\mathrm{CCM}$ reflected the residue from feeds and drugs given to the chicken. Previous studies had traced high content of heavy metals in poultry manure to feeds and drugs administered on the birds (Zhang et al. 2005; Van Zanten et al. 2014; Oguntade et al. 2019). However, $\mathrm{Co}, \mathrm{Cr}$ and $\mathrm{Pb}$ were below detection limits in both

247 the conventional and local manure.

Table 2 shows the effects of chicken manure amendment on chemical properties of the soil. 
Table 2 Effects of chicken manure amendment on chemical properties of soil at 6 WAS

\begin{tabular}{|c|c|c|c|c|c|c|c|c|c|c|c|c|c|c|}
\hline \multirow{3}{*}{$\begin{array}{l}\text { Sources of } \\
\text { Variation }\end{array}$} & \multirow[t]{3}{*}{$\mathrm{pH}$} & \multirow{2}{*}{$\begin{array}{l}\text { Total } \\
\mathrm{N}\end{array}$} & \multirow{2}{*}{$\begin{array}{l}\text { Org. } \\
\text { C }\end{array}$} & \multirow{3}{*}{$\begin{array}{l}\text { Avail P } \\
\left(\mathrm{mg} \mathrm{kg}^{-1}\right)\end{array}$} & & \multirow[b]{2}{*}{$\mathrm{Ca}$} & \multirow[b]{2}{*}{$\mathrm{K}$} & \multirow[b]{2}{*}{$\mathrm{Mg}$} & \multirow[b]{2}{*}{$\mathrm{Na}$} & \multirow[b]{2}{*}{ ECEC } & \multicolumn{4}{|c|}{ Extractable } \\
\hline & & & & & $\mathrm{Al}+\mathrm{H}$ & & & & & & $\mathrm{Cu}$ & $\mathrm{Fe}$ & $\mathrm{Mn}$ & $\mathrm{Zn}$ \\
\hline & & \multicolumn{2}{|c|}{$\left(\mathrm{g} \mathrm{kg}^{-1}\right)$} & & \multicolumn{6}{|c|}{$\left(\mathrm{cmol} \mathrm{kg}^{-1}\right)$} & \multicolumn{4}{|c|}{$\left(\mathrm{mg} \mathrm{kg}^{-1}\right)$} \\
\hline \multicolumn{15}{|l|}{$\begin{array}{l}\text { Manure } \\
\text { sources }\end{array}$} \\
\hline Conventional & 6.08 & 0.75 & 6.30 & 12.88 & 0.13 & 6.99 & 0.18 & 3.55 & 0.70 & 11.54 & 1.56 & 3.01 & 18.91 & 1.26 \\
\hline Local & 5.93 & 0.56 & 4.15 & 10.82 & 0.14 & 6.31 & 0.14 & 3.43 & 0.81 & 10.82 & 1.15 & 3.60 & 14.54 & 0.93 \\
\hline (sig.) & $* * *$ & $* * *$ & $* * *$ & $* * *$ & $* *$ & $* * *$ & $* * *$ & $\mathrm{~ns}$ & $* * *$ & $* * *$ & $* * *$ & $* * *$ & $* * *$ & $* * *$ \\
\hline LSD & 0.02 & 0.07 & 0.13 & 0.08 & 0.01 & 0.07 & 0.01 & 0.13 & 0.01 & 0.17 & 0.03 & 0.03 & 0.18 & 0.03 \\
\hline \multicolumn{15}{|l|}{$\begin{array}{l}\text { Manure rates } \\
\left(\mathrm{t} \mathrm{ha}^{-1}\right)\end{array}$} \\
\hline 0 & 5.77 & 0.65 & 8.07 & 7.09 & 0.11 & 5.58 & 0.10 & 3.08 & 0.31 & 9.16 & 0.64 & 1.67 & 9.77 & 0.40 \\
\hline 4 & 6.00 & 0.80 & 5.48 & 9.97 & 0.13 & 6.12 & 0.12 & 3.32 & 0.81 & 10.51 & 1.17 & 3.33 & 14.19 & 0.99 \\
\hline 6 & 6.12 & 0.55 & 4.75 & 12.64 & 0.13 & 6.48 & 0.15 & 3.53 & 0.92 & 11.20 & 1.42 & 3.43 & 16.90 & 1.10 \\
\hline 8 & 6.10 & 0.60 & 3.62 & 14.16 & 0.14 & 6.79 & 0.18 & 3.62 & 0.94 & 11.66 & 1.64 & 3.85 & 19.96 & 1.37 \\
\hline 10 & 6.02 & 0.68 & 4.22 & 15.39 & 0.14 & 8.28 & 0.24 & 3.91 & 0.80 & 13.37 & 1.90 & 4.25 & 22.81 & 1.60 \\
\hline (sig.) & $* * *$ & $* *$ & $* * *$ & $* * *$ & $* * *$ & $* * *$ & $* * *$ & $* * *$ & $* * *$ & $* * *$ & $* * *$ & $* * *$ & $* * *$ & $* * *$ \\
\hline LSD & 0.03 & 0.11 & 0.20 & 0.13 & 0.01 & 0.10 & 0.01 & 0.21 & 0.02 & 0.27 & 0.05 & 0.05 & 0.28 & 0.04 \\
\hline \multicolumn{15}{|l|}{ Manure } \\
\hline sources $\mathrm{x}$ & $* * *$ & $* *$ & $* * *$ & $* * *$ & ns & $* * *$ & $* *$ & $\mathrm{~ns}$ & $* * *$ & $* * *$ & $* * *$ & $* * *$ & $* * *$ & $* * *$ \\
\hline \multicolumn{15}{|l|}{ Rates } \\
\hline LSD & 0.04 & 0.16 & 0.28 & 0.19 & 0.01 & 0.15 & 0.02 & 0.30 & 0.02 & 0.38 & 0.06 & 0.07 & 0.40 & 0.06 \\
\hline
\end{tabular}


Except for exchangeable acidity, $\mathrm{Na}$ and $\mathrm{Fe}$, the chemical properties of soil increased significantly in soil amended with CCM over LCM. Generally, the soil chemical properties increased significantly with manure rate irrespective of the sources. The interaction of sources and rates of manure was also significant on the soil chemical properties except for exchangeable acidity and $\mathrm{Mg}$. Across manure rates, CCM showed positive relationships with $\mathrm{OC}$, total $\mathrm{N}$ and available $\mathrm{P}$ unlike LCM with negative relationships except at $10 \mathrm{tha}^{-1}$. The CCM at $4 \mathrm{tha}^{-1}$ maintained a strong direct relationship with total $\mathrm{N}$ 257 and $\mathrm{OC}$. The CCM at $10 \mathrm{t} \mathrm{ha}^{-1}$ had the strongest and most direct relationships with available $\mathrm{P}$ while $6 \mathrm{t}$ $258 \mathrm{ha}^{-1}$ had the least influence. Amendment with $6 \mathrm{t} \mathrm{ha}^{-1}$ of the CCM directly reversed the low $\mathrm{pH}$ of the soil. 259 On the other hand LCM showed strong association with the $\mathrm{pH}$, ECEC among other soil chemical properties. Although, $8 \mathrm{t} \mathrm{ha}^{-1}$ of LCM had the highest influence on the ECEC and $\mathrm{pH}$, its effect on the soil OC and total $\mathrm{N}$ was negative. Meanwhile, the LCM was more directly associated with $\mathrm{pH}$ at $4 \mathrm{t} \mathrm{ha}^{-1}$ but had stronger effect on the ECEC at $6 \mathrm{t} \mathrm{ha}^{-1}$ (Fig. 1). The trace metals $(\mathrm{Cu}, \mathrm{Fe}, \mathrm{Mn}$ and $\mathrm{Zn})$ among other nutrients were highest in soil amended with the highest manure rate of $10 \mathrm{t} \mathrm{ha}^{-1}$. This observation was a reflection of the nutrient content of the two manure sources. The inverse relationships exhibited by CCM on the soil $\mathrm{pH}$ and ECEC can be attributed to its strong alkalinity. The higher accumulation of trace metals in soil which increased with manure rate indicated potential soil pollution. Kobierski et al. (2017)

267 have also reported increased soil chemical properties in soil fertilized with poultry manure.

The effect of chicken manure amendment on total concentration and pollution index of the selected heavy metals is shown in Table 3. Total concentration of $\mathrm{Cd}, \mathrm{Cu}$ and $\mathrm{Mn}$ as well as their pollution indices (CF, DC, EPI, PLI and TCF) in amended soil were significantly $(p \leq 0.001)$ higher with

271 CCM than LCM. Total concentration of metal in soil at the lowest manure rate of $4 \mathrm{t} \mathrm{ha}^{-1}$ was

272 significantly higher than in control soil without amendment. Concentration of Cd at the lowest manure 273 rate of $4 \mathrm{t} \mathrm{ha}^{-1}$ was above $3 \mathrm{mg} \mathrm{kg}^{-1}$ limit allowable by FAO/WHO (2001) and European Commission 274 (2006). Meanwhile across rates of amendments, $\mathrm{Cu}$ and $\mathrm{Mn}$ were below the soil limits of 100 and 2000 $275 \mathrm{mg} \mathrm{kg}^{-1}$, respectively. Heavy metal pollution of soil increased significantly with manure rate with the 


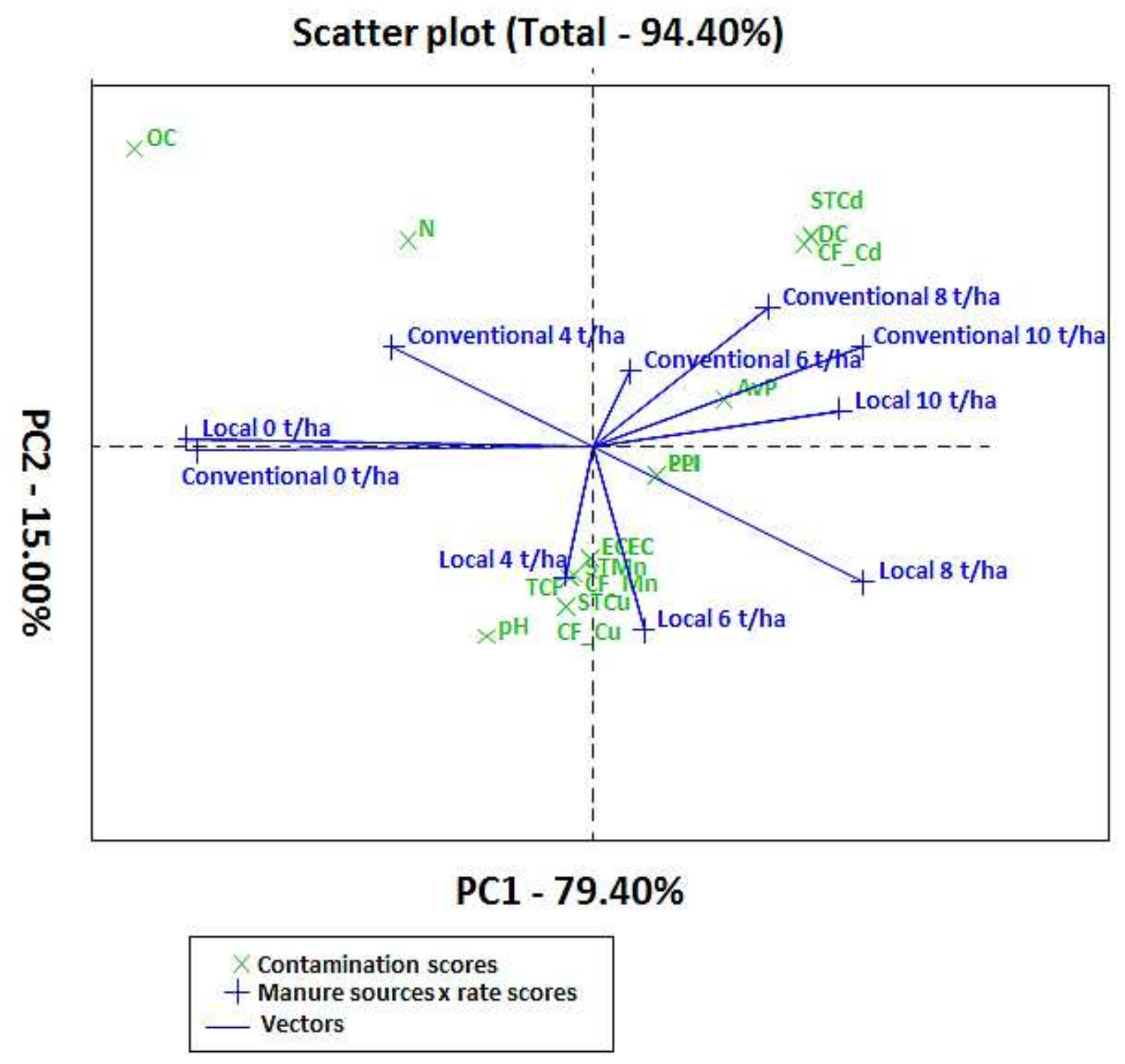

277 Fig. 1 Principal component analysis biplot of manure sources and rates on soil chemical properties, metal 278 concentration and pollution indices.

279 
Table 3 Influence of chicken manure amendment on the contamination and pollution of soil by cadmium, copper and manganese at 6 WAS

\begin{tabular}{|c|c|c|c|c|c|c|c|c|c|c|}
\hline $\begin{array}{l}\text { Sources of } \\
\text { Variation }\end{array}$ & $\begin{array}{l}\text { Total Soil- } \\
\mathrm{Cd}\end{array}$ & $\begin{array}{l}\text { Total Soil- } \\
\mathrm{Cu} \\
\left(\mathrm{mg} \mathrm{kg}^{-1}\right) \\
\end{array}$ & $\begin{array}{l}\text { Total Soil- } \\
\text { Mn }\end{array}$ & CF-Cd & $\mathrm{CF}-\mathrm{Cu}$ & CF-Mn & $\mathrm{DC}$ & EPI & PLI & TCF \\
\hline $\begin{array}{l}\text { Manure } \\
\text { sources }\end{array}$ & & & & & & & & & & \\
\hline Conventional & 4.58 & 12.61 & 316.31 & 130.93 & 3.15 & 0.29 & 134.37 & 26.12 & 4.87 & 0.30 \\
\hline $\begin{array}{l}\text { Local } \\
\text { (sig.) }\end{array}$ & $\begin{array}{l}3.69 \\
* * *\end{array}$ & $\underbrace{12.15}_{* * *}$ & $\begin{array}{l}298.84 \\
* * *\end{array}$ & $\begin{array}{l}105.45 \\
* * *\end{array}$ & $\begin{array}{l}3.04 \\
* * * *\end{array}$ & $\begin{array}{l}0.27 \\
* * *\end{array}$ & 108.76 & $\underset{* * *}{23.54}$ & $\begin{array}{l}4.39 \\
* * *\end{array}$ & $\begin{array}{l}0.29 \\
* * *\end{array}$ \\
\hline $\begin{array}{l}\text { LSD } \\
\text { Manure rates } \\
\left(\mathrm{t} \mathrm{ha}^{-1}\right)\end{array}$ & 0.07 & 0.05 & 1.89 & 1.85 & 0.01 & 0.01 & 1.85 & 0.15 & 0.03 & 0.01 \\
\hline 0 & 1.88 & 10.06 & 250.16 & 53.57 & 2.51 & 0.23 & 56.31 & 16.77 & 2.13 & 0.24 \\
\hline 4 & 3.47 & 12.35 & 304.25 & 99.24 & 3.09 & 0.27 & 102.60 & 23.52 & 4.39 & 0.29 \\
\hline 6 & 4.08 & 12.79 & 312.64 & 116.48 & 3.20 & 0.28 & 119.96 & 25.25 & 4.71 & 0.30 \\
\hline 8 & 5.25 & 13.07 & 327.59 & 150.10 & 3.27 & 0.30 & 153.66 & 28.19 & 5.26 & 0.31 \\
\hline $\begin{array}{l}10 \\
\text { (sig.) }\end{array}$ & $\underset{* * * *}{6.01}$ & $\begin{array}{l}13.62 \\
* * * *\end{array}$ & $\begin{array}{l}343.24 \\
* * * *\end{array}$ & ${ }_{* * *}^{171.57}$ & $\begin{array}{l}3.40 \\
* * * *\end{array}$ & ${ }_{* * * *}^{0.31}$ & ${ }_{* * *}^{175.29}$ & $\begin{array}{l}30.39 \\
* * * *\end{array}$ & $\begin{array}{l}5.67 \\
* * *\end{array}$ & $\begin{array}{l}0.33 \\
* * * *\end{array}$ \\
\hline LSD & 0.10 & 0.09 & 2.98 & 2.92 & 0.02 & 0.01 & 2.92 & 0.23 & 0.04 & 0.01 \\
\hline $\begin{array}{l}\text { Manure } \\
\text { sources x } \\
\text { Rates }\end{array}$ & $* * *$ & $* * *$ & $* * *$ & *** & **** & **** & *** & $* * *$ & $* * *$ & $* * *$ \\
\hline LSD & 0.15 & 0.12 & 4.22 & 4.13 & 0.03 & 0.01 & 4.13 & 0.33 & 0.06 & 0.01 \\
\hline
\end{tabular}


282

283

284

highest metal load at $10 \mathrm{t} \mathrm{ha}^{-1}$. Interaction of manure sources and rates was also significant for the soil pollution indices. The CCM across rates contributed directly to the total soil Cd, CF-Cd and DC. The contribution was highest at $10 \mathrm{t} \mathrm{ha}^{-1}$ and least at $6 \mathrm{tha}^{-1}$. However, while the $8 \mathrm{t} \mathrm{ha}^{-1}$ showed the strongest relationships, the $4 \mathrm{t} \mathrm{ha}^{-1}$ had weakest relationships with the indices (Fig. 1). Unlike the CCM, the LCM across rate except at $10 \mathrm{tha}^{-1}$ was more associated with total soil $\mathrm{Cu}, \mathrm{CF}-\mathrm{Cu}$, total soil $\mathrm{Mn}, \mathrm{CF}-\mathrm{Mn}, \mathrm{TCF}$ and PLI. The $8 \mathrm{t} \mathrm{ha}^{-1}$ of LCM had the strongest and the most direct influence on the PLI. Meanwhile, the $6 \mathrm{t} \mathrm{ha}^{-1}$ had stronger association than $4 \mathrm{t} / \mathrm{ha}$ with the $\mathrm{Cu}$ and $\mathrm{Mn}$ soil contamination factors. Indices like $\mathrm{CF}$ and DC showed that the amended soil was very highly polluted with $\mathrm{Cd}$, moderate with $\mathrm{Cu}$ and low in Mn since the $\mathrm{CF}$ values was $>6$ for $\mathrm{Cd} ; 1 \leq \mathrm{CF} \geq 3$ for $\mathrm{Cu}$ and $\mathrm{CF}<1$ for Mn (Gong et al. 2008; Goher et al. 2014). The PLI of 2.14 in control soil which was moderately contaminated may be attributed to geochemical or local background of the soil (Dung et al. 2013). However, at amendment rates of 4 and $6 \mathrm{t}$ $\mathrm{ha}^{-1}$, PLI value of the soil reflected a severe contamination. At manure rates of 8 and $10 \mathrm{tha} \mathrm{ha}^{-1}$, the PLI were 5.26 and 5.67, respectively which indicated that the soil was extremely contaminated due to PLI $\geq 5$ (Tomlinson et al. 1980). The TCF also showed that the higher the rate of manure amendment the higher the metal loads in the soil. This further reinforced the effects of chicken manure rate of $6 \mathrm{tha} \mathrm{h}^{-1}$ and above on soil metal pollution loads which farmers should be wary of to minimize toxic metals transfer to food crops. Enrichment of soils with organic fertilizer amendments can contribute to heavy metals load in agricultural soils (Su et al. 2014; Kowalska et al. 2018).

Except for shoot dry weight, the growth and yield characteristics of Celosia argenta were not affected by chicken manure sources (Table 4). This showed that chicken manure from both sources have similar effects on growth and yield potentials of Celosia argentea. Soil amendment with chicken manure of $4 \mathrm{t} \mathrm{ha}^{-1}$ significantly $(p \leq 0.001)$ increased plant height, numbers of leaves and primary branches as well as yield of Celosia argentea over no amendment (control). Generally, the growth and yield attributes increased significantly with increased manure rate up to $8 \mathrm{t} \mathrm{ha}^{-1}$, above which the attributes declined. Chicken manure amendment of $8 \mathrm{t} \mathrm{ha}^{-1}$ was not significantly different from $6 \mathrm{t} \mathrm{ha}^{-1}$ in all parameters. 
307 Table 4 Mean effects of chicken manure amendment on growth and dry matter yield of Celosia argentea at 6 WAS

\begin{tabular}{|c|c|c|c|c|c|c|c|}
\hline \multirow[t]{2}{*}{$\begin{array}{l}\text { Sources of } \\
\text { Variation }\end{array}$} & Plant height & $\begin{array}{l}\text { No of leaves } \\
\text { plant }^{-1}\end{array}$ & $\begin{array}{l}\text { No of primary } \\
\text { branches plant }{ }^{-1}\end{array}$ & $\begin{array}{l}\text { Shoot fresh } \\
\text { weight }\end{array}$ & $\begin{array}{l}\text { Root fresh } \\
\text { weight }\end{array}$ & $\begin{array}{l}\text { Shoot dry } \\
\text { weight }\end{array}$ & Root dry weight \\
\hline & $(\mathrm{cm})$ & & & \multicolumn{4}{|c|}{ (g) } \\
\hline \multicolumn{8}{|l|}{ Manure sources } \\
\hline Conventional & 50.19 & 31.00 & 21.87 & 39.56 & 7.38 & 3.20 & 0.91 \\
\hline Local & 47.55 & 30.27 & 21.53 & 37.34 & 6.97 & 2.32 & 0.67 \\
\hline (sig.) & ns & ns & ns & $\mathrm{ns}$ & $\mathrm{ns}$ & $* *$ & ns \\
\hline LSD & 5.00 & 1.88 & 2.52 & 10.19 & 1.84 & 0.63 & 0.25 \\
\hline \multicolumn{8}{|l|}{$\begin{array}{l}\text { Manure rates } \\
\left(\mathrm{t} \mathrm{ha}^{-1}\right)\end{array}$} \\
\hline 0 & 28.67 & 22.50 & 9.33 & 9.91 & 3.06 & 0.97 & 0.26 \\
\hline 4 & 46.80 & 30.17 & 21.83 & 33.67 & 4.49 & 2.58 & 0.56 \\
\hline 6 & 57.90 & 34.67 & 26.67 & 47.20 & 10.19 & 3.31 & 1.04 \\
\hline 8 & 60.17 & 34.66 & 27.83 & 51.22 & 10.26 & 3.83 & 1.19 \\
\hline 10 & 50.82 & 31.17 & 22.83 & 50.23 & 7.86 & 3.10 & 0.91 \\
\hline (sig.) & $* * *$ & $* * *$ & $* * *$ & $* * *$ & *** & $* * *$ & **** \\
\hline LSD & 7.91 & 2.97 & 3.98 & 16.11 & 2.90 & 0.99 & 0.39 \\
\hline \multicolumn{8}{|c|}{ Manure sources } \\
\hline x Rates & $*$ & $* *$ & $*$ & ns & $*$ & ns & ns \\
\hline LSD & 11.19 & 4.21 & 5.63 & 22.78 & 4.10 & 1.40 & 0.56 \\
\hline
\end{tabular}


312 Manure rate of $6 \mathrm{tha}^{-1}$ was also not different from $4 \mathrm{t} \mathrm{ha}^{-1}$ in shoot fresh and dry weights. The optimum 313 dry matter yield at $8 \mathrm{t} \mathrm{ha}^{-1}$ might have been influenced by soil pollution factors induced by the 314 amendment. According to Kalavrouziotis and Koukoulakis (2012), dry matter yield of plant was a 315 reference point in determining extent of soil pollution through CF or PLI. In pot culture such as in this 316 study, it is economical, better and healthier to amend soil with chicken manure at $4 \mathrm{t} \mathrm{ha}^{-1}$ than higher rate.

317 Application of $4 \mathrm{tha}^{-1}$ in this study still gave the optimum yield, this will reduce buildup of heavy metals 318 in soil and consequently lower transfer to the food chain. The interaction of manure sources and the rates 319 was also significant for plant height, numbers of leaves, primary branches and root fresh weight.

Bioaccumulation of $\mathrm{Cu}$ and $\mathrm{Mn}$ was significantly higher in tissues of celosia grown on CCM than 321 LCM except for TF-Cu where LCM was higher than CCM (Table 5). Bioaccumulation of both Cu and 322 Mn increased significantly with manure rate over no amendment (control) soil. Meanwhile, BAC of $\mathrm{Cu}$ in 323 the tissues of celosia which initially declined from 0.94 in no amendment soil to 0.88 at $4 \mathrm{t} \mathrm{ha}^{-1}$ was $>1$ at 3248 and $10 \mathrm{t} \mathrm{ha}^{-1}$ with highest of 1.09 at $10 \mathrm{tha}^{-1}$. Conversely, the highest BAC values of $0.19-0.22$ were 325 recorded for $\mathrm{Mn}$ at $6-10 \mathrm{t} \mathrm{ha}^{-1}$. In a similar trend to $\mathrm{BAC}-\mathrm{Cu}$, the $\mathrm{BCF}-\mathrm{Cu}$ also declined from 0.75 to 3260.72 at 0 and $4 \mathrm{tha}^{-1}$, respectively. Thereafter, a significant increase in BCF-Cu of up to 1 was observed 327 with manure rate at $10 \mathrm{t} \mathrm{ha}^{-1}$. However, BCF-Mn increased with rate of amendment significantly and was highest at $8 \mathrm{tha}^{-1}$. The TF of $\mathrm{Cu}$ and $\mathrm{Mn}$ from amended soil to plant decreased with manure rate from 0 to $6 \mathrm{t} \mathrm{ha}^{-1}$ for $\mathrm{Cu}$ and through $8 \mathrm{tha}^{-1}$ for Mn. There were no significant differences in TF-Mn at 4 and $6 \mathrm{tha}$ ${ }^{1}$ of the amendment. Interaction of manure sources and rate showed that $\mathrm{BAC}$ and $\mathrm{BCF}$ of $\mathrm{Cu}$ and $\mathrm{Mn}$ increased significantly with manure rate in celosia tissues. Metal accumulation potential of celosia varied 332 with types of manure and rates. The BAC-Cu and BCF-Cu in tissues of celosia were strongly influenced 333 by the CCM in the order $10>8>6 \mathrm{t} \mathrm{ha}^{-1}$. Only the $10 \mathrm{t} / \mathrm{ha}$ of LCM had direct relationships with least 334 effect on bioaccumulation of $\mathrm{Cu}$ (Fig. 2). Conversely, BAC-Mn and BCF-Mn were directly and strongly 335 influenced by LCM in the order $8>6 \mathrm{tha}^{-1}$. However, CCM at $4 \mathrm{t} / \mathrm{ha}$ also exhibited a direct but weak 336 association with BAC-Mn and BCF-Mn while it maintained an inverse relationships with BAC-Cu and 
337 Table 5 Bioaccumulation of heavy metals in root and shoot tissues of Celosia argentea grown on soil 338 amended with chicken manure at 6 WAS

\begin{tabular}{|c|c|c|c|c|c|c|}
\hline $\begin{array}{l}\text { Sources of } \\
\text { Variation }\end{array}$ & $\mathrm{BAC}-\mathrm{Cu}$ & BAC-Mn & $\mathrm{BCF}-\mathrm{Cu}$ & BCF-Mn & TF-Cu & TF-Mn \\
\hline \multicolumn{7}{|l|}{$\begin{array}{l}\text { Manure } \\
\text { sources }\end{array}$} \\
\hline Conventional & 1.01 & 0.21 & 0.92 & 0.18 & 1.11 & 1.17 \\
\hline Local & 0.94 & 0.18 & 0.80 & 0.17 & 1.19 & 1.07 \\
\hline (sig.) & $* * *$ & $* * *$ & $* * *$ & $* * *$ & $* * *$ & $* * *$ \\
\hline LSD & 0.01 & 0.01 & 0.02 & 0.01 & 0.02 & 0.02 \\
\hline \multicolumn{7}{|l|}{$\begin{array}{l}\text { Manure rates } \\
\left(\mathrm{t} \mathrm{ha}^{-1}\right)\end{array}$} \\
\hline 0 & 0.94 & 0.17 & 0.75 & 0.13 & 1.25 & 1.27 \\
\hline 4 & 0.88 & 0.18 & 0.72 & 0.16 & 1.23 & 1.13 \\
\hline 6 & 0.92 & 0.22 & 0.89 & 0.20 & 1.05 & 1.11 \\
\hline 8 & 1.05 & 0.21 & 0.94 & 0.21 & 1.13 & 1.03 \\
\hline 10 & 1.09 & 0.19 & 1.00 & 0.18 & 1.09 & 1.06 \\
\hline (sig.) & $* * *$ & $* * *$ & $* * *$ & $* * *$ & $* * *$ & $* * *$ \\
\hline LSD & 0.02 & 0.01 & 0.03 & 0.01 & 0.04 & 0.03 \\
\hline $\begin{array}{l}\text { Manure } \\
\text { sources x } \\
\text { Rates }\end{array}$ & $* * *$ & $* * *$ & $* * *$ & $* * *$ & $* * *$ & $* * *$ \\
\hline LSD & 0.03 & 0.01 & 0.04 & 0.01 & 0.05 & 0.04 \\
\hline
\end{tabular}

\footnotetext{
$=$ significant at $p \leq 0.001$
} 

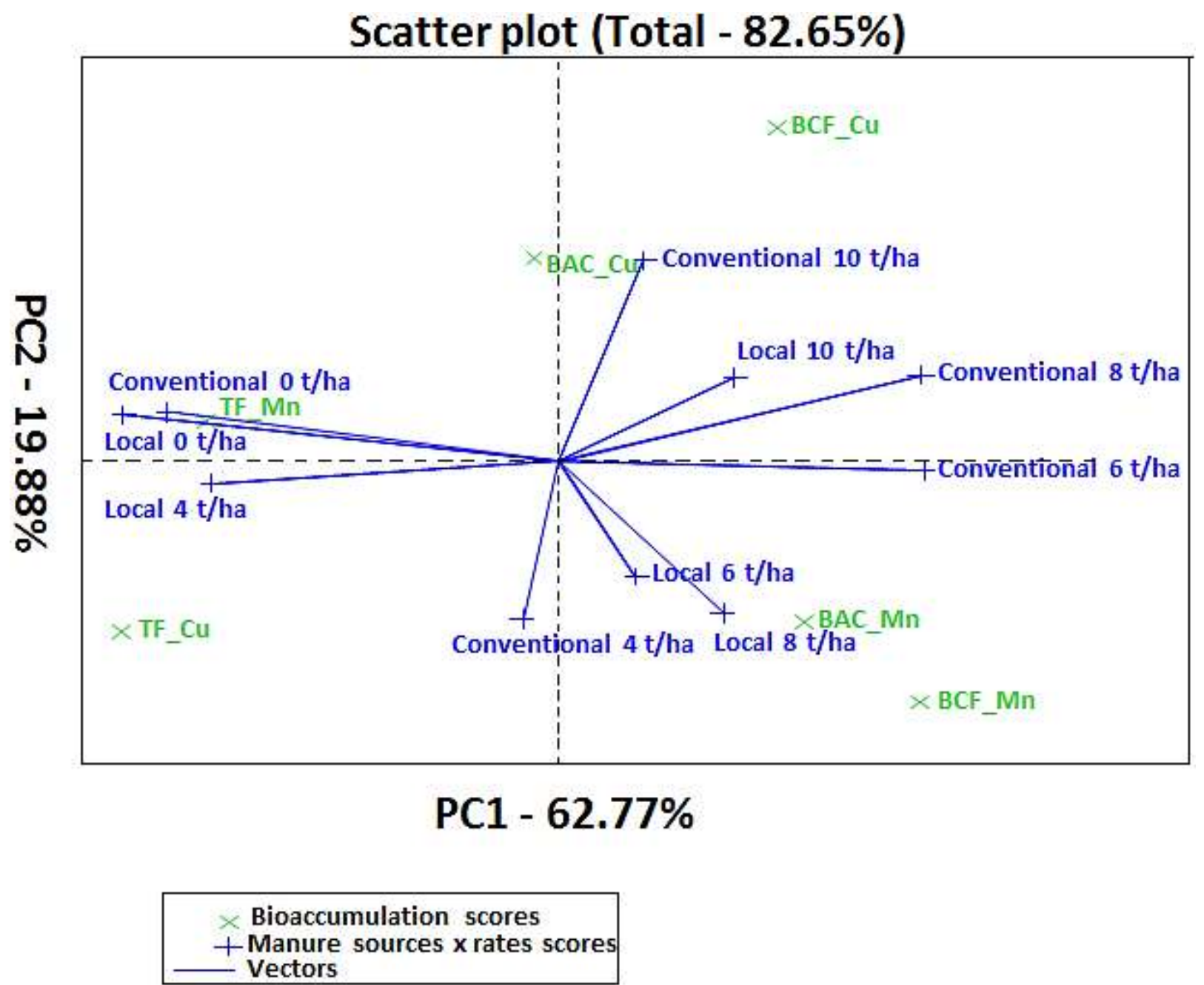

347 Fig. 2 Principal component analysis biplot of manure sources and rates on bioaccumulation of heavy 348 metal in tissues of Celosia argentea 
BCF-Cu. The TF was highest for $\mathrm{Mn}$ and $\mathrm{Cu}$ in the control soil followed by soil amended with $4 \mathrm{t} \mathrm{ha}^{-1}$. At $4 \mathrm{t} \mathrm{ha}^{-1}$, the LCM had stronger relationships with transfer factor of both metals than CCM. The association showed that at $4 \mathrm{tha}^{-1}$, LCM contributed more to TF of both $\mathrm{Cu}$ and $\mathrm{Mn}$ than CCM, though the effect was higher for TF-Cu. According to Hanen et al. (2010) the total amount of metals that accumulate in shoot is the most important feature that determines phytoextraction potential of a plant. This observation indicated that extraction and bioaccumulation of $\mathrm{Cu}$ was higher than $\mathrm{Mn}$ by celosia despite higher total concentration of $\mathrm{Mn}$ in the soil. Hence, bioaccumulation capacity of celosia is more of metal dependent than total concentration in the soil. Celosia can therefore, be regarded as good extractor of $\mathrm{Cu}$ but poor extractor of $\mathrm{Mn}$ from the amended soil. Studies have shown that plants with BAC value of $>1$ are promising phytoextractor of heavy metals (Fitz and Wenzel 2002; Amin et al. 2018). Hence, soil amendment with chicken manure above $6 \mathrm{t} \mathrm{ha}^{-1}$ is not encouraged for cultivation of celosia to reduce bioaccumulation of metal in the edible shoot and minimize food chain contamination. The $\mathrm{Cu} \mathrm{BCF}$ of 1 at 8 and $10 \mathrm{t} \mathrm{ha}^{-1}$ manure rate indicated that celosia can suitably extract significant amount of $\mathrm{Cu}$ than $\mathrm{Mn}$ from the growth medium (Jamali et al. 2009). This means that there is potential danger of human exposure to $\mathrm{Cu}$ when celosia grown on soil amended with chicken manures above $6 \mathrm{t} \mathrm{ha}^{-1}$ is consumed.

371 According to Ugulu et al. (2021) bioconcentration factor is a key component of determining exposure of 372 potentially toxic metals via the food chain. The low accumulation of $\mathrm{Mn}$ in celosia tissues than $\mathrm{Cu}$ is an 373 indication of tolerance to Mn hence, restriction of its transfer from soil to root and root to shoot (Yoon et 374 al. 2006). The $\mathrm{TF}$ of $>1$ for both $\mathrm{Cu}$ and $\mathrm{Mn}$ showed that celosia is a potential extractor of these metals 375 (Yoon et al. 2006; Amin et al. 2018). This signified that $\mathrm{Cu}$ and $\mathrm{Mn}$ extracted from the amended soil were 376 transferred to edible shoot of the vegetable with potential risks of food chain contamination. The highest $377 \mathrm{TF}$ of $\mathrm{Cu}$ and $\mathrm{Mn}$ in control soil without amendment in this study was similar to previous observation of 378 Beesley et al. (2014) and Oguntade et al. (2018). They opined that metal ions are freely available in soil 379 without organic amendment and hence exhibited low metals binding potentials due to low soil $\mathrm{pH}$ and 380 organic matter. Our observation of close association exhibitted by LCM at $4 \mathrm{t} \mathrm{ha}^{-1}$ to TF-Mn and TF-Cu 381 unlike CCM at $4 \mathrm{t} \mathrm{ha}^{-1}$ which contributed more to OC corroborate this earlier assertions. The declined TF 
with manure rate was therefore a reflection of, complexation, chelation and adsorption capacity exhibited by ligands in the organic manure (Chiu et al. 2006; Beesley et al. 2014; Oguntade et al. 2017). However, chicken manure rate of between 4 and $6 \mathrm{t} \mathrm{ha}^{-1}$ may be reasonable for this purpose to reduce soil metal contamination at higher rates. celosia grown on soil amended with CCM than LCM. The concentration and uptake of both metals were higher in shoot than root of the vegetable. The lowest $\mathrm{Cu}$ concentration of 9.42 and $7.55 \mathrm{mg} \mathrm{kg}^{-1}$ was recorded in shoot and root, respectively from the soil without manure amendment. Meanwhile, at the 391 highest manure rate of $10 \mathrm{t} \mathrm{ha}^{-1}$, concentration of $\mathrm{Cu}$ in shoot and root was 14.85 and $13.63 \mathrm{mg} \mathrm{kg}^{-1}$, 392 respectively. Cadmium was below detection limit in tissues of the vegetable. However, shoot and root$393 \mathrm{Mn}, \mathrm{Cu}$-uptake as well as Mn-uptake which increased significantly with manure rate was highest at $8 \mathrm{tha}^{-}$ $394{ }^{1}$ and decreased afterwards. Copper uptake by root at $6 \mathrm{t} \mathrm{ha}^{-1}$ was not different from $8 \mathrm{t} \mathrm{ha}^{-1}$. Similarly, Mn 395 uptake by celosia roots and shoots at 6 and $8 \mathrm{t} \mathrm{ha}^{-1}$ was not different significantly. The interaction of 396 manure sources and the rate of amendment were significant for concentrations of $\mathrm{Cu}$ and $\mathrm{Mn}$ in root and 397 shoot tissues of celosia but not significant for its uptake. The decline in metals uptake despite higher 398 concentration at higher rates of amendment could be due to presence of soluble organic matter which may 399 have chelated the metals amidst increased $\mathrm{pH}$ of the amended soil. Other authors have also observed that 400 combination of organic matter and elevated $\mathrm{pH}$ of soils limits bioavailability of heavy metals in plants 401 thus, reduces uptake (Jung and Thornton 1996; Rosselli et al. 2003; Yoon et al. 2006). Higher 402 concentration of metals in shoot than root in this study was an indication of mobility of the metals to 403 upper part of the plant. This was contrary to reports of Yoon et al. (2006) who found higher 404 concentrations of metals $(\mathrm{Pb}, \mathrm{Cu}$ and $\mathrm{Zn})$ in root than shoot of plant samples due to low mobility.

405 Table 7 shows the correlation matrix of celosia growth, yield and concentration of selected heavy metals 
406 Table 6 Concentrations and uptake of heavy metals by root and shoot tissues of Celosia argentea grown on soil amended with chicken manure 407 from different sources at 6 WAS

\begin{tabular}{|c|c|c|c|c|c|c|c|c|c|c|}
\hline \multirow[t]{2}{*}{$\begin{array}{l}\text { Sources of } \\
\text { Variation }\end{array}$} & shoot-Cu & root-Cu & shoot-Cd & root-Cd & shoot-Mn & root-Mn & $\begin{array}{l}\text { shoot-Cu } \\
\text { uptake }\end{array}$ & $\begin{array}{l}\text { root-Cu } \\
\text { uptake }\end{array}$ & $\begin{array}{l}\text { shoot-Mn } \\
\text { uptake }\end{array}$ & $\begin{array}{l}\text { root-Mn } \\
\text { uptake }\end{array}$ \\
\hline & \multicolumn{6}{|c|}{$\left(\mathrm{mg} \mathrm{kg}^{-1}\right)$} & \multicolumn{4}{|c|}{$\left(\mathrm{mg} \mathrm{plant}^{-1}\right)$} \\
\hline \multicolumn{11}{|l|}{$\begin{array}{l}\text { Manure } \\
\text { sources }\end{array}$} \\
\hline Conventional & 12.82 & 11.78 & BDL & BDL & 66.71 & 57.80 & 0.043 & 0.012 & 0.23 & 0.060 \\
\hline $\begin{array}{l}\text { Local } \\
\text { (sig.) }\end{array}$ & $\begin{array}{l}11.49 \\
* * *\end{array}$ & $\begin{array}{l}9.74 \\
* * * *\end{array}$ & BDL & BDL & $\begin{array}{l}53.90 \\
* * *\end{array}$ & $\begin{array}{l}51.59 \\
* * *\end{array}$ & 0.028 & 0.007 & $\begin{array}{l}0.13 \\
* * *\end{array}$ & $\begin{array}{l}0.039 \\
* *\end{array}$ \\
\hline \multicolumn{11}{|l|}{$\begin{array}{l}\text { Manure rates } \\
\left(\mathrm{t} \mathrm{ha}^{-1}\right)\end{array}$} \\
\hline 0 & 9.42 & 7.55 & BDL & $\mathrm{BDL}$ & 41.32 & 32.53 & 0.009 & 0.002 & 0.04 & 0.009 \\
\hline 4 & 10.88 & 8.88 & BDL & $\mathrm{BDL}$ & 55.23 & 48.82 & 0.028 & 0.005 & 0.15 & 0.028 \\
\hline 6 & 11.82 & 11.42 & BDL & $\mathrm{BDL}$ & 69.15 & 61.87 & 0.039 & 0.013 & 0.23 & 0.068 \\
\hline 8 & 13.80 & 12.32 & BDL & BDL & 70.67 & 68.90 & 0.054 & 0.016 & 0.27 & 0.086 \\
\hline $\begin{array}{l}10 \\
\text { (sig.) }\end{array}$ & 14.85 & 13.63 & BDL & $\mathrm{BDL}$ & $\begin{array}{l}65.17 \\
* * *\end{array}$ & $\begin{array}{l}61.37 \\
* * *\end{array}$ & $\begin{array}{l}0.046 \\
* * *\end{array}$ & $\begin{array}{l}0.013 \\
* * *\end{array}$ & $\begin{array}{l}0.20 \\
* * *\end{array}$ & $\begin{array}{l}0.056 \\
* * *\end{array}$ \\
\hline LSD & 0.22 & 0.31 & & & 1.19 & 0.85 & 0.01 & 0.01 & 0.07 & 0.02 \\
\hline $\begin{array}{l}\text { Manure } \\
\text { sources } \\
\text { Rates }\end{array}$ & $* * *$ & $* * *$ & & & **** & $* * *$ & ns & ns & ns & ns \\
\hline LSD & 0.31 & 0.44 & & & 1.69 & 1.20 & 0.02 & 0.01 & 0.09 & 0.03 \\
\hline
\end{tabular}


Table 7 Relationships between growth, yield of celosia and total concentration of heavy metals in soil amended with chicken manure

\begin{tabular}{|c|c|c|c|c|c|c|c|c|}
\hline & $\begin{array}{l}\text { No of } \\
\text { primary } \\
\text { braches }\end{array}$ & No of leaf & Plant height & Root DMY & Shoot DMY & $\begin{array}{l}\text { Total soil- } \\
\mathrm{Cd}\end{array}$ & $\begin{array}{l}\text { Total soil- } \\
\mathrm{Cu}\end{array}$ & $\begin{array}{l}\text { Total soil- } \\
\text { Mn }\end{array}$ \\
\hline & & & $(\mathrm{cm})$ & & (g) & & $\left(\mathrm{mg} \mathrm{kg}^{-1}\right)$ & \\
\hline $\begin{array}{l}\text { No of primary } \\
\text { braches }\end{array}$ & - & & & & & & & \\
\hline No of leave & $0.97^{* * *}$ & - & & & & & & \\
\hline Plant height & $0.97^{* * * *}$ & $0.96^{* * * *}$ & - & & & & & \\
\hline Root DMY & $0.68^{* * * *}$ & $0.71^{* * * *}$ & $0.75^{* * * *}$ & - & & & & \\
\hline Shoot DMY & $0.79^{* * * *}$ & $0.76^{* * * *}$ & $0.84^{* * * *}$ & $0.75^{* * * *}$ & - & & & \\
\hline Total soil-Cd & $0.65^{* * *}$ & $0.63^{* * *}$ & $0.68^{* * * *}$ & $0.66^{* * * *}$ & $0.72^{* * *}$ & - & & \\
\hline Total soil- $\mathrm{Cu}$ & $0.71^{* * * *}$ & $0.68^{* * * *}$ & $0.71^{* * * *}$ & $0.64^{* * * *}$ & $0.71^{* * * *}$ & $0.91^{* * * *}$ & - & \\
\hline Total soil-Mn & $0.66^{* * *}$ & $0.63^{* * * *}$ & $0.67^{* * * *}$ & $0.65^{* * * *}$ & $0.72^{* * *}$ & $0.94^{* * * *}$ & $0.99^{* * * *}$ & - \\
\hline
\end{tabular}

significant at $p \leq 0.001 ;$ DMY = Dry Matter Yield

411

412

413

414 
415 in soil amended with chicken manure. Significant associations were found between growth, yield 416 characteristics of celosia and total concentration of $\mathrm{Cd}, \mathrm{Cu}$ and $\mathrm{Mn}$ in the amended soil. This indicates 417 that significant amount of $\mathrm{Cd}, \mathrm{Cu}$ and $\mathrm{Mn}$ taken up by celosia from the soil actually contributed to the 418 growth and yield. In a previous study by (Oguntade et al. 2019), a significant correlation was reported 419 between the growth, yield and heavy metals ( $\mathrm{Cu}$ and $\mathrm{Mn}$ ) uptake by Jute mallow (Corchorus olitorius) a 420 similar leafy vegetable. Hanč et al. (2008) had also reported that close relationship exists between $\mathrm{Cu}$ 421 taken up by oat and its biomass yield.

Correlation coefficients of selected soil properties, TF, root and shoot uptake of $\mathrm{Cu}$ and $\mathrm{Mn}$ as well as bioaccumulation of $\mathrm{Cu}$ and $\mathrm{Mn}$ in tissues of celosia are shown in Table 8 . Soil $\mathrm{pH}$ significantly 424 and directly influenced ECEC, root-Cu uptake, root-Mn uptake, shoot-Cu uptake, shoot-Mn uptake and 425 bioaccumulation of $\mathrm{Cu}$ and $\mathrm{Mn}$ in celosia tissues. Meanwhile, the $\mathrm{pH}$ was inversely related with $\mathrm{TF}$ of the 426 metals with a significant negative relationship with TF-Cu $\left(\mathrm{r}=-0.79^{* * *}\right)$. This showed that increased $\mathrm{pH}$ 427 of amended soil lowered TF of the metals which was significant for $\mathrm{Cu}$. Soil organic carbon was 428 significantly and negatively correlated with ECEC $\left(\mathrm{r}=-0.49^{* *}\right)$ but strongly correlated with TF-Mn $(\mathrm{r}=$ $\left.4290.85^{* * *}\right)$. Though the correlation between organic carbon, uptake and bioaccumulation of $\mathrm{Cu}$ and $\mathrm{Mn}$ were not significant, an inverse relationship exists amongst them. According to Jung and Thornton (1996); 431 Rosselli et al. (2003) combination of high organic matter and soil pH are key determinants in reducing heavy metal uptake by plants. A significant negative relationship was found between ECEC, TF-Cu $(r=-$ $\left.0.55^{* *}\right)$ and TF-Mn $\left(\mathrm{r}=-0.44^{*}\right)$. This showed that as the soil exchange site was buffered with cations, TF of $\mathrm{Cu}$ and $\mathrm{Mn}$ into celosia tissues decreased. However, the relationship between ECEC, root and shoot uptake as well as bioaccumulation of $\mathrm{Cu}$ and $\mathrm{Mn}$ were positive. Generally, the TF of $\mathrm{Cu}$ and Mn were significantly and negatively correlated with uptake and bioaccumulation of the metals in celosia tissues.

437 Root uptake of $\mathrm{Cu}$ and $\mathrm{Mn}$ were significantly $(p \leq 0.001)$ and positively correlated with each other as well as with $\mathrm{BAC}$ and $\mathrm{BCF}$ of both metals. A similar relationship was observed between shoot uptake of the metals, its $\mathrm{BAC}$ and $\mathrm{BCF}$. Except for $\mathrm{BAC}$ of $\mathrm{Cu}$ and $\mathrm{Mn}$ which was not significant, the relationships 
Table 8 Relationships between soil properties, metal transfer, uptake and bioaccumulation in tissues of celosia at 6 WAS

\begin{tabular}{|c|c|c|c|c|c|c|c|c|c|c|c|c|c|}
\hline & $\mathrm{pH}$ & Org C. & ECEC & $\mathrm{TF}-\mathrm{Cu}$ & TF-Mn & $\begin{array}{l}\text { Root-Cu } \\
\text { uptake }\end{array}$ & $\begin{array}{l}\text { Root- } \\
\text { Mn } \\
\text { uptake }\end{array}$ & $\begin{array}{l}\text { Shoot- } \\
\mathrm{Cu} \\
\text { uptake }\end{array}$ & $\begin{array}{l}\text { Shoot- } \\
\text { Mn } \\
\text { uptake }\end{array}$ & $\begin{array}{l}\text { BAC- } \\
\mathrm{Cu}\end{array}$ & $\begin{array}{l}\text { BAC- } \\
\text { Mn }\end{array}$ & $\mathrm{BCF}-\mathrm{Cu}$ & $\begin{array}{l}\mathrm{BCF}- \\
\mathrm{Mn}\end{array}$ \\
\hline $\begin{array}{l}\mathrm{pH} \\
\text { Org }\end{array}$ & $\begin{array}{l}- \\
-0.24^{\mathrm{ns}}\end{array}$ & - & & & & & & & & & & & \\
\hline C. & & & & & & & & & & & & & \\
\hline ECEC & $0.56^{* *}$ & $-0.49^{* *}$ & - & & & & & & & & & & \\
\hline $\mathrm{TF}-\mathrm{Cu}$ & $-0.79^{* * *}$ & $0.13^{\mathrm{ns}}$ & $-0.55^{* *}$ & - & & & & & & & & & \\
\hline $\begin{array}{l}\text { TF- } \\
\mathrm{Mn}\end{array}$ & $-0.29^{n s}$ & $0.85^{* * *}$ & $-0.44^{*}$ & $0.06^{\mathrm{ns}}$ & - & & & & & & & & \\
\hline $\begin{array}{l}\text { Root- } \\
\mathrm{Cu} \\
\text { uptake }\end{array}$ & $0.71^{* * *}$ & $-0.28^{\mathrm{ns}}$ & $0.64^{* * *}$ & $-0.65^{* * *}$ & $-0.37^{*}$ & - & & & & & & & \\
\hline $\begin{array}{l}\text { Root- } \\
\text { Mn } \\
\text { uptake }\end{array}$ & $0.74^{* * *}$ & $-0.33^{\mathrm{ns}}$ & $0.58^{* * *}$ & $-0.61^{* * *}$ & $-0.45^{*}$ & $0.98^{* * *}$ & - & & & & & & \\
\hline $\begin{array}{l}\text { Shoot- } \\
\mathrm{Cu} \\
\text { uptake }\end{array}$ & $0.78^{* * *}$ & $-0.31^{\mathrm{ns}}$ & $0.70^{* * *}$ & $-0.62^{* * *}$ & $-0.44^{*}$ & $0.79^{* * *}$ & $0.80^{* * *}$ & - & & & & & \\
\hline $\begin{array}{l}\text { Shoot- } \\
\text { Mn } \\
\text { uptake }\end{array}$ & $0.86^{* * *}$ & $-0.22^{\mathrm{ns}}$ & $0.59^{* * *}$ & $-0.70^{* * *}$ & $-0.30^{\mathrm{ns}}$ & $0.77^{\text {*** }}$ & $0.80^{* * *}$ & $0.96^{* * *}$ & - & & & & \\
\hline $\begin{array}{l}\text { BAC- } \\
\mathrm{Cu}\end{array}$ & $0.38^{*}$ & $-0.14^{\mathrm{ns}}$ & $0.75^{* * *}$ & $-0.47^{* *}$ & $-0.22^{\mathrm{ns}}$ & $0.64^{* * *}$ & $0.56^{* *}$ & $0.66^{* * *}$ & $0.53^{* *}$ & - & & & \\
\hline $\begin{array}{l}\text { BAC- } \\
\text { Mn }\end{array}$ & $0.81^{* * *}$ & $-0.02^{\mathrm{ns}}$ & $0.35^{\mathrm{ns}}$ & $-0.71^{* * *}$ & $0.06^{\mathrm{ns}}$ & $0.50^{* *}$ & $0.55^{* *}$ & $0.57^{* *}$ & $0.73^{* * *}$ & $0.34^{\mathrm{ns}}$ & - & & \\
\hline $\begin{array}{l}\mathrm{BCF}- \\
\mathrm{Cu}\end{array}$ & $0.69^{* * *}$ & $-0.13^{\mathrm{ns}}$ & $0.74^{* * *}$ & $-0.86^{* * *}$ & $-0.13^{\mathrm{ns}}$ & $0.74^{* * *}$ & $0.67^{* * *}$ & $0.74^{* * * *}$ & $0.72^{\text {**** }}$ & $0.85^{\text {*** }}$ & $0.62^{\text {**** }}$ & - & \\
\hline $\begin{array}{l}\text { BCF- } \\
\mathrm{Mn}\end{array}$ & $0.83^{* * *}$ & $-0.50^{* *}$ & $0.52^{* *}$ & $-0.61^{* * *}$ & $-0.53^{* *}$ & $0.64^{* * *}$ & $0.73^{* * *}$ & $0.73^{* * *}$ & $0.79^{* * *}$ & $0.43^{*}$ & $0.81^{\text {*** }}$ & $0.60^{* * *}$ & - \\
\hline
\end{tabular}

$* * *, * *, *=$ Significant at $p \leq 0.001,0.01,0.05$, respectively; $n s=$ not significant; WAS = weeks after sowing 
441 between $\mathrm{BAC}$ and $\mathrm{BCF}$ of $\mathrm{Cu}$ and $\mathrm{Mn}$ in tissues of celosia were positive. The positive and significant 442 relationship showed that the metals were taken up by the root, translocated to edible shoot and 443 accumulated in tissues of celosia.

444 Conclusion

445 Soil amendment with $\mathrm{CCM}$ contributed significant amount of metals $(\mathrm{Cu}, \mathrm{Cd}$ and $\mathrm{Mn})$ to soil pollution 446 indices compared to LCM. Heavy metals pollution of amended soil increased with manure rates.

447 Bioaccumulation of heavy metals in celosia tissues increased with rate of amendment. Phytoextraction 448 potentials of $\mathrm{Cu}$ by celosia was higher compared to $\mathrm{Mn}$. Mobility of metals from soil via the root to shoot 449 tissues depends not only on total concentration in soil but also on the type of metals involved. Soil 450 amendment with chicken manures above $6 \mathrm{t} \mathrm{ha}^{-1}$ is not encouraged to avoid buildup of toxic metals in 451 soils and its subsequent transfer to food crops.

452

453

454

455

456

457

458

459

460

461

462

463

464

465

466

467

\section{Declarations}

Ethics approval: $\quad$ Not applicable

Consent to participate: Not applicable.

Consent for publication: Not applicable.

Funding information: Not applicable

Availability of data and materials: All datasets generated and used for the current study are available

from the corresponding author on reasonable request.

Competing interests: The authors declare no competing interests.

Authors' contributions: Conceptualization and methodology was done by Oladele Abdulahi Oguntade; Formal analysis and investigation were done by Oladele Abdulahi Oguntade, Nosiru Monday Yisa and Solomon Oladimeji Olagunju; Writing - original draft preparation was by Oladele Abdulahi Oguntade; Writing - review and editing were done by all co-authors; Funding acquisition involved all co-authors; Resources were made available by Oladele Abdulahi Oguntade, Olufemi Sunday Sosanya, Abiodun 
471 Oladipupo Joda, Kayode Matthew Adewusi and Richard Oluseyi Olayiwola while supervision was done

472 by Oladele Abdulahi Oguntade and Nosiru Monday Yisa.

473 Acknowledgements: The authors are grateful to Prof. F. O. Olasantan who painstakingly edited the

474 manuscript.

475

476

477

478

479

480

481

482

483

484

485

486

487

488

489

490

491

492

493

494

495

496

497

498

499

500

501

502

503

504

505

506

507

\section{REFERENCES}

Adeli A, Sistani KR, Tewolde H, Rowe DE (2007) Broiler litter application effects on selected trace elements under conventional and no-till systems. Soil Science 172(5): 349-365. https://doi.org/10.1097/ss.0b013e318032ab7d

Adeoye GO, Agboola AA (1985) Critical levels for soil pH, available P, K, Zn and Mn and maize ear-leaf content of $\mathrm{P}, \mathrm{Cu}$ and $\mathrm{Mn}$ in sedimentary soils of South-Western Nigeria. Fertilizer Research 6(1): 65-71. https://doi.org/10.1007/BF01058165

Alam MGM, Snow ET, Tanaka A (2003) Arsenic and heavy metal contamination of rice, pulses and vegetables grown in Samta village, Bangladesh. Arsenic Exposure and Health Effects V 308: 103114. https://doi.org/10.1016/B978-044451441-7/50009-9

Amin H, Arain BA, Jahangir TM, Sadiq M, Amin F (2018) Accumulation and distribution of lead ( Pb ) in plant tissues of guar (Cyamopsis tetragonoloba L.) and sesame (Sesamum indicum L.): profitable phytoremediation with biofuel crops. Geology, Ecology, and Landscapes 9508: 1-10. https://doi.org/10.1080/24749508.2018.1452464

Anderson JM, Ingram JSI (1993) Soil organic matter and organic carbon. In 'Tropical soil biology and fertility: a handbook of method of analysis'. Anderson JM Ingram JSI (Eds.), CAB International: Wallingford, UK. pp. 62-70.

Antonious GF, Kochhar TS, Coolong T (2012) Yield, quality, and concentration of seven heavy metals in cabbage and broccoli grown in sewage sludge and chicken manure amended soil. Journal of Environmental Science and Health - Part A Toxic/Hazardous Substances and Environmental Engineering, 47(13): 1955-1965. https://doi.org/10.1080/03601234.2012.676509

Baker AJM (1981) Accumulators and Excluders - Strategies in the Response of Plants to Heavy Metals. Journal of Plant Nutrition 3(1-4): 643-654. https://doi.org/10.1080/01904168109362867

Bandow N, Simon FG (2016) Significance of cadmium from artists' paints to agricultural soil and the food chain. Environmental Sciences Europe, 28: 12. https://doi. org/10.1186/s12302-016-0077-6.

Beesley L, Inneh OS, Norton GJ, Moreno-Jimenez E, Pardo T, Clemente R, Dawson JJC (2014) Assessing the influence of compost and biochar amendments on the mobility and toxicity of metals and arsenic in a naturally contaminated mine soil. Environmental Pollution 186: 195-202. https://doi.org/10.1016/j.envpol.2013.11.026

Bouyoucos GH (1962) Hydrometer method for making particle size analysis of soils. Agronomy Journal 54: 464-465. https://doi.org/10.2134/agronj1962.00021962005400050028x. 
Bremner JM, Mulvaney CS (1982) Nitrogen-Total. In: Methods of soil analysis. Part 2. Chemical and microbiological properties, Page AL, Miller RH, Keeney DR, Eds., American Society of Agronomy, Soil Science Society of America, Madison, Wisconsin, 595-624.

Bu-Olayan A.H, Thomas B.T (2009) Translocation and bioaccumulation of trace metals in desert plants of Kuwait Governorates. Research Journal of Environmental Sciences 3(5): 581-587 https://doi.org/10.3923/rjes.2009.581.587

Cabrera F, Clemente L, Díaz Barrientos E, López R, Murillo JM (1999) Heavy metal pollution of soils affected by the Guadiamar toxic flood. Science of the Total Environment, 242(1-3): 117-129. https://doi.org/10.1016/S0048-9697(99)00379-4

Chastain JP, Camberato JJ, Skewes P (2010) Poultry Manure Production and Nutrient Content. Production, October 2014, 1-17.

Chiu KK, Ye ZH, Wong MH (2006) Growth of Vetiveria zizanioides and Phragmities australis on $\mathrm{Pb} / \mathrm{Zn}$ and $\mathrm{Cu}$ mine tailings amended with manure compost and sewage sludge: A greenhouse study. Bioresource Technology 97(1): 158-170. https://doi.org/10.1016/j.biortech.2005.01.038

Dung TTT, Cappuyns V, Swennen R, Phung NK (2013) From geochemical background determination to pollution assessment of heavy metals in sediments and soils. Reviews in Environmental Science and Biotechnology, 12(4): 335-353. https://doi.org/10.1007/s11157-013-9315-1

Esu IE (1991) Detailed soil survey of Nigerian Institute for Horticultural Research (NIHORT) farm at Bunkure, Kano State, Nigeria. Institute for Agricultural Research, A.B.U. Zaria. 72 pp.

Eugenio NR, Naidu R, Colombo CM (2020) Global approaches to assessing, monitoring, mapping, and remedying soil pollution. Environmental Monitoring and Assessment, 192(9): 601. https://doi.org/10.1007/s10661-020-08537-2.

European Commission (2006) Commission Regulation (EC) No. 1881/2006 of 19 December 2006 setting maximum levels for certain contaminants in foodstuffs. Off J Eur Union 364:5-24.

FAO (Food and Agricultural Organization) (1976) A framework for land evaluation. FAO. Soils Bull 32, FAO, Rome. 87 pp.

FAO/WHO (2001) Codex Alimentarius Commission. Food additive and contaminants. Joint FAO/ WHO Food Standards Programme, ALINORM 01/ 12A, pp 1-289.

Fiori CS, Rodrigues AP, Santelli RE, Cordeiro RC, Carvalheira RG, Araujo PC, Castilhos ZC, Bidone ED (2013) Ecological risk index for aquatic pollution control: a case study of coastal water bodies from the Rio de Janeiro State, southeastern Brazil. Geochimica Brasiliensis, 27(1): 24-36. https://doi.org/10.21715/gb.v27i1.386.

Fitz WJ, Wenzel WW (2002) Arsenic transformations in the soil-rhizosphere-plant system: Fundamentals and potential application to phytoremediation. Journal of Biotechnology, 99(3): 259-278. https://doi.org/10.1016/S0168-1656(02)00218-3

Goher ME, Farhat HI, Abdo MH, Salem SG (2014) Metal pollution assessment in the surface sediment of Lake Nasser, Egypt. Egyptian Journal of Aquatic Research, 40(3): 213-224. https://doi.org/10.1016/j.ejar.2014.09.004. 
Gong Q, Deng J, Xiang Y, Wang Q, Yang L (2008) Calculating pollution indices by heavy metals in ecological geochemistry assessment and a case study in parks of Beijing. Journal of China University of Geosciences 19(3): 230-241. https://doi.org/10.1016/S1002-0705(08)60042-4.

Håkanson L (1980) An ecological risk index for aquatic pollution control. A sedimentological approach. Water Research 14(8): 975-1001. https://doi.org/10.1016/0043-1354(80)90143-8

Hanč A, Tlustoš P, Száková J, Habart J, Gondek K (2008) Direct and subsequent effect of compost and poultry manure on the bioavailability of cadmium and copper and their uptake by oat biomass. Plant, Soil and Environment 54(7): 271-278.

Hough RL, Young SD, Crout NMJ (2003) Modelling of Cd, Cu, Ni, Pb and Zn uptake, by winter wheat and forage maize, from a sewage disposal farm. Soil Use and Management 19(1): 19-27. https://doi.org/10.1079/sum2002157

Islam MS, Ahmed MK, Al-Mamun MH, Masunaga S (2015) Potential ecological risk of hazardous elements in different land-use urban soils of Bangladesh. Sci Total Environ 512-513: 94-102. http://dx.doi.org/10.1016/j.scitotenv.2014.12.100.

Jamali MK, Kazi TG, Arain MB, Afridi HI, Jalbani N, Kandhro GA, Shah AQ, Baig JA (2009) Heavy metal accumulation in different varieties of wheat (Triticum aestivum L.) grown in soil amended with domestic sewage sludge. Journal of Hazardous Materials, 164(2-3): 1386-1391. https://doi.org/10.1016/j.jhazmat.2008.09.056

Jorfi S, Maleki R, Jaafarzadeh N, Ahmadi M (2017) Pollution load index for heavy metals in Mian-Ab plain soil, Khuzestan, Iran. Data in Brief, 15: 584-590. https://doi.org/10.1016/j.dib.2017.10.017

Jung MC, Thornton I (1996) Heavy metal contamination of soils and plants in the vicinity of a lead-zinc mine, Korea. Applied Geochemistry 11:53-59. https://doi.org/10.1016/0883-2927(95)00075-5.

Kalavrouziotis IK, Koukoulakis PH (2012) Soil pollution under the effect of treated municipal wastewater. Environmental Monitoring and Assessment, 184(10): 6297-6305. https://doi.org/10.1007/s10661-011-2420-0

Khan MN, Mobin M, Abbas ZK, Alamri SA (2017) Fertilizers and their contaminants in soils, surface and groundwater. In Encyclopedia of the Anthropocene 1-5: Elsevier Inc. https://doi.org/10.1016/B978-0-12-809665-9.09888-8

Kobierski M, Bartkowiak A, Lemanowicz J, Piekarczyk M (2017) Impact of poultry manure fertilization on chemical and biochemical properties of soils. Plant, Soil and Environment, 63(12): 558-563. https://doi.org/10.17221/668/2017-PSE

Kowalska JB, Mazurek R, Gąsiorek M, Zaleski T (2018) Pollution indices as useful tools for the comprehensive evaluation of the degree of soil contamination-A review. Environmental Geochemistry and Health 40(6): 2395-2420. https://doi.org/10.1007/s10653-018-0106-z

Luo L, Ma Y, Zhang S, Wei D, Zhu YG (2009) An inventory of trace element inputs to agricultural soils in China. Journal of Environmental Management 90(8): 2524-2530. https://doi.org/10.1016/j.jenvman.2009.01.011

McLean EO, Dumford SWF, Coronel SW (1982) A comparison of several methods of determining lime requirements of soil. Soil Science Society of America Proceedings 30: 26-30. 
Mortola N, Romaniuk R, Cosentino V, Eiza M, Carfagno P, Rizzo P, Bres P, Riera N, Roba M, Butti M, Sainz D, Brutti L (2019) Potential Use of a Poultry Manure Digestate as a Biofertiliser: Evaluation of Soil Properties and Lactuca sativa Growth. Pedosphere 29(1): 60-69. https://doi.org/10.1016/S1002-0160(18)60057-8

Nelson DW, Sommers LE (1996) Total carbon, organic carbon, and organic matter. In 'Methods of soil analysis. Part 3'. Sparke DL (Ed.). Chemical methods SSSA book series no: Madison, ASA and SSSA 5. pp. 961-1010.

Nicholson FA, Chambers BJ, Williams JR, Unwin RJ (1999) Heavy metal contents of livestock feeds and animal manures in England and Wales. Bioresource Technology 70(1): 23-31. https://doi.org/10.1016/S0960-8524(99)00017-6

Oguntade OA, Odusanya OA, Olagunju SO, Oduntan OB, Adewusi KM, Adegoke AT (2017) Residual effect of composted poultry manure on yield and bioaccumulation of Iron , Zinc, Lead and Cadmium in tissues of Common Cockscomb (Celosia argentea L .) grown on soils from waste dumpsite and farmland. African Journal of Agriculture Technology and Environment 6(1): 79-88.

Oguntade OA, Odusanya OA, Olagunju SO, Adewusi KM, Adegoke AT (2018). Residual effect of composted kitchen waste and poultry manure soil amendments on yield and concentrations of copper, iron, manganese and zinc in leaf tissue of Jute mallow (Corchorus Olitorius Linn). Ife Journal of Agriculture 30(2): 65-76.

Oguntade OA, Olagbenro TS, Odusanya OA, Olagunju SO, Adewusi KM, Adegoke AT (2019) Assessment of composted kitchen waste and poultry manure amendments on growth, yield and heavy metal uptake by Jute mallow Corchorus olitorius Linn. International Journal of Recycling of Organic Waste in Agriculture 8(2): 187-195. https://doi.org/10.1007/s40093-018-0232-8

Oguntade OA, Adegbuyi AA, Nassir AL, Olagunju SO, Salami WA, Adewale RO (2020) Geoassessment of heavy metals in rural and urban floodplain soils: health implications for consumers of Celosia argentea and Corchorus olitorius vegetables in Sagamu, Nigeria. Environmental Monitoring and Assessment 192(3): 164. https://doi.org/10.1007/s10661-020-8077-9

Rosselli W, Keller C, Boschi K (2003) Phytoextraction capacity of trees growing on a metal contaminated soil. Plant and Soil 256: 265-272.

Salem HM, Eweida EA, Farag A (2000) Heavy metals in drinking water and their environmental impact on human health. ICEHM, 542-556.

Shakoor MB, Niazi NK, Bibi I, Murtaza G, Kunhikrishnan A, Seshadri B, Shahid M, Ali S, Bolan NS, Ok YS, Abid M, Ali F (2016) Remediation of arsenic-contaminated water using agricultural wastes as biosorbents. Critical Reviews in Environmental Science and Technology 46(5): 467-499. https://doi.org/10.1080/10643389.2015.1109910

Shomar B, Kalavrouziotis IK (2013) Soil Pollution Indices Under the Effect of Sludge. Water Air Soil Pollut 224:1436. https://doi.org/10.1007/s11270-013-1436-1

Sobulo RA, Osiname OA (1981) Soils and fertilizer use in Western Nigeria. Research Bulletin Institute of Agriculture Research and Training 11: 20-26 pp. Ibadan.

Spark DL (1995) Environmental Soil Chemistry. Academic Press: San Diego, Cambridge, MA, USA. 
Su C, Jiang L, Zhang W (2014) A review on heavy metal contamination in the soil worldwide: Situation, impact and remediation techniques. Environmental Skeptics and Critics 3(2): 24-38

Tomlinson DC, Wilson JG, Harris CR, Jeffrey DW (1980) Problems in the assessment of heavy metals levels in estuaries and the formation of pollution index. Helgolander Wissenschaff Meeresuntersuchungen 33: 566-569.

Turekian KK, Wedepohl KH (1961) Distribution of the elements in some major units of the Earth's crust. Geological Society of American Bulletin 72(2): 175-192. https://doi.org/10.1130/00167606(1961)72[175:DOTEIS]2.0.CO;2.

Udo EJ, Ibis TO, Ogunwale JA, Ano AO, Esu IE (2009) Manual of Soil, Plant and Water Analysis. Sibon Books Ltd: Lagos.

Ugulu I, Ahmad K, Khan ZI, Munir M, Wajid K, Bashir H (2021) Effects of organic and chemical fertilizers on the growth, heavy metal/metalloid accumulation, and human health risk of wheat (Triticum aestivum L.). Environmental Science and Pollution Research 28(10): 12533-12545. https://doi.org/10.1007/s11356-020-11271-4

Van Zanten HHE, Mollenhorst H, De Vries JW, Van Middelaar CE, Van Kernebeek HRJ, De Boer IJM (2014) Assessing environmental consequences of using co-products in animal feed. International Journal of Life Cycle Assessment 19(1): 79-88. https://doi.org/10.1007/s11367-013-0633-x

Wajid K, Ahmad K, Iqbal Z, Muhammad K (2020) Pattern of trace metal uptake in Pearl millet as a result of application of organic and synthetic fertilizers. International Journal of Environmental Research. https://doi.org/10.1007/s41742-020-00287-w

Walkley A, Black IA (1934) An examination of the degtjareff method for determining soil organic matter, and a proposed modification of the chromic acid titration method. In Soil Science 37(1): 29-38. https://doi.org/10.1097/00010694-193401000-00003

Yoon J, Cao X, Zhou Q, Ma LQ (2006) Accumulation of $\mathrm{Pb}, \mathrm{Cu}$, and $\mathrm{Zn}$ in native plants growing on a contaminated Florida site. Science of the Total Environment 368(2-3): 456-464. https://doi.org/10.1016/j.scitotenv.2006.01.016

Zhang SQ, Zhang FD, Liu XM, Wang YJ, Zou SW, He XS (2005) Determination and analysis on main harmful composition in excrement of scale livestock and poultry feedlots. Plant Nutr Fert Sci 11:822-829.

Zhang F, Li Y, Yang M, Li W (2012) Content of heavy metals in animal feeds and manures from farms of different scales in Northeast China. International Journal of Environmental Research and Public Health 9(8): 2658-2668. https://doi.org/10.3390/ijerph9082658. 